\title{
Stakeholder Participation in Project Initiation: A Foundation to Completion of Urban Road Transport Infrastructure Projects, Kenya
}

\author{
Johnson Matu ${ }^{1, ~}$, Dorothy Ndunge Kyalo ${ }^{2}$, John Mbugua ${ }^{2}$, Angeline Sabina Mulwa ${ }^{2}$ \\ ${ }^{1}$ Project Planning and Management, University of Nairobi, Nairobi, Kenya \\ ${ }^{2}$ School of Open and Distance Learning, University of Nairobi, Nairobi, Kenya
}

Email address:

matupec@gmail.com (J. Matu),ndunge.kyalo@yahoo.com (D. N. Kyalo), mbugua04@yahoo.com (J. Mbugua), asmulwa2008@yahoo.com (A. S. Mulwa)

${ }^{*}$ Corresponding author

\section{To cite this article:}

Johnson Matu, Dorothy Ndunge Kyalo, John Mbugua, Angelina Sabina Mulwa. Stakeholder Participation in Project Initiation: A Foundation to Completion of Urban Road Transport Infrastructure Projects, Kenya. Journal of Civil, Construction and Environmental Engineering. Vol. 5, No. 1, 2019, pp. 11-19. doi: 10.11648/j.jccee.20200501.12

Received: November 9, 2019; Accepted: December 7, 2019; Published: March 24, 2020

\begin{abstract}
Cost overrun and delays are major impediments to project completion in road construction industry globally. Stakeholder participation in construction cycle could present a solution to these challenges. The purpose of this study was therefore, to examine the influence of stakeholder participation in project initiation on completion of urban road transport infrastructure projects in Kenya. The unit of analysis was the road construction projects implemented by Kenya Urban Roads Authority (KURA). Pragmatic research paradigm was chosen for this study to facilitate mixed research methods. The study adopted descriptive survey and correlational research designs. The target population was 1593 and the sample size was 309 respondents. Purposive and simple random sampling procedures were utilized. A five-point Likert type scale questionnaire was used to collect quantitative data while interview guides were used to collect qualitative data. The study then applied both descriptive and inferential statistics for the data analysis. The study found that participation in project initiation had a positive and significant influence on the completion of urban road transport infrastructure projects in Kenya $\left(r=0.859, \mathrm{R}^{2}=0.737, \mathrm{~F}(1\right.$, $212)=594.869, \mathrm{p}<0.001<0.05)$. The study established that there was a positive influence of participation in project initiation on completion of urban road transport infrastructure projects in Kenya. The study recommends formulation of a policy framework to sensitize stakeholders on their participation in project initiation, project design and project construction to enhance effective project implementation and completion. The study recommends hiring of competent and experienced project managers to ensure effective implementation of urban road transport infrastructure.
\end{abstract}

Keywords: Stakeholder Participation, Stakeholder Engagement, Project Initiation, Urban Road Transport Infrastructure Projects

\section{Introduction}

The involvement of stakeholders at the inception stage of a project is imperative as it brings interested parties and their interests on board $[1,2]$. If this stage is not executed soundly, it is improbable that the project will be effective in achieving the community needs [3]. Moreover, Lennon, Dunphy, \& Sanvicente [4] showed demonstrable examples of how extended stakeholder perspectives can improve outcomes. During project initiation prominence must placed on idea generation, prioritization and project feasibility studies, screening and selection. Moreover, early stakeholder involvement allows room for creative solutions and the intensive exchange of ideas leading to better outcomes [5].

Project preparation includes setting goals, various inputs, resettlement, and infrastructure development. It is necessary to develop mechanisms for the selection of projects that ensure fairness and avoid conflicts of interest. The initiation procedures determine the nature and scope of the project. The crucial project controls needed at this stage are an 
understanding of the project environment and making sure that the essential controls are amalgamated into the project. Any deficiencies should be reported and a recommendation made to fix them. The initiation stage should include stakeholder identification and analysis, comprising; users, and support workers for the project. As well as project charter containing; costs, tasks, deliverables and the schedule [6].

During the inception phase, stakeholders conduct a needs analysis by identifying needs and prioritizing them [7]. Once the problem has been identified, beneficiaries discuss it at length and reach a consensus. The objective analysis is done and a possible solution examined based on the root cause of the problem. During initiation, a needs analysis by stakeholders can serve as a guide to ensure that the project initiation is in line with the needs and capabilities of the said community. This should be the guiding principle in deciding whether community participation is possible and practical during project construction. The facts found in the preliminary stage will be valuable in reaching such a conclusion [8]. When stakeholders are involved in identifying their needs they are able to have a common understanding of a problem, treat it with the importance it deserves, and commit to solving the problem [9].

Early involvement of project stakeholders provide a productive discourse and ownership that may lead to increased credibility, transparency and the early identification of limits. Tammer [2] argued that if this process is not handled appropriately, it may turn out to be a (costly) burden. In order to properly align all points of view and even contradictory and diverging interests, a comprehensive and complete stakeholder identification and classification should take place during project initiation. [10,11]

This study is premised on the stakeholder theory propounded by Freeman [12]. Freeman asserts that the goal of a project is to generate the best value for stakeholders. The theory pinpoints and models stakeholders groups of a project. The theory also describes and recommends approaches through which management can meet the interests of those groups [13]. Stakeholder theory is principally a management theory, which claims that power and urgency must be observed if managers are to meet the welfares of stakeholders. The stakeholder theory addresses the principle of who actually matters in the projects or business environment. It encourages managers to articulate the shared sense of the value they create and what brings its core stakeholders together [14]. Freeman further posits that stakeholder theory is managerial in that it reflects and directs how managers operate with its focus being based on two core questions that are what is the purpose of a firm and what responsibility does management have to stakeholders. This drives managers to produce good performance and to be expressive of what kind of relations they want to create with their stakeholders so as to deliver on their purpose. This implies that stakeholders are significant constituents in any activity.

The theory is therefore relevant in the evaluation of urban roads transport infrastructure projects in the identification of the key stakeholders and their influence on project completion [14]. Most of the projects whether donor-funded or government sponsored have failed to fully embrace stakeholder participatory approaches mostly in the project initiation stage. Failure in project implementation is due to exclusion of public in the initiation phase [4]. Several studies have shown that participatory development can lead to high rate of project acceptance and utilization [15-17].

\section{Literature Review}

Stakeholder participation is a critical component of road transport construction project management. Construction projects impact different stakeholders with dissimilar social, environmental and economic outcomes. It is therefore, essential that the decision makers maintain effective communication with relevant groups to avoid project failure [18]. Lindborg [19] traces the origins of modern stakeholder participation thinking back to the 1930 s to a debate on the responsibilities of corporations. The Stanford Research Institute introduced the definition of stakeholder in 1963, the concept was not linked with management strategy until the publication of R. Edward Freeman's in 1984. Freeman noted that business decisions without ethics could lead to dreadful concerns, and started to look at integrating ethics into organizational strategy [20]. This new significance of stakeholder engagement emerged together with the quality movement that is founded on the notion that everybody involved in the creation and consumption of products or services is responsible for their quality. Freeman sees the two movements as complementary to one another. He also espouses the view that risk and profit should be secondary to the process of stakeholder engagement and management. Stakeholders play a critical role across the project cycle, however, the initiation phase of the project cycle is critical because it lays the foundation for the project [21].

Project initiation is the starting phase of the project construction cycle. According to Abowitz and Toole [22], the initiation phase of the construction cycle of infrastructure projects play an important part in planning, execution and determines the end result of the entire project. The purpose of the initiation phase is to determine if sufficient demand exists for the project to begin collecting the necessary background information for project development. Ideally, this is the stage where stakeholders are identified and the project team is constituted. Aken [23] observed that during the project initiation phase, the needs are identified and prioritized by the stakeholders who also identify the root causes of the problems. Mulwa [24] observed that needs identification is important in developing the capacity of grassroots communities. According to Maddaloni and Davis [25], seeking local community opinions in the initiation phase of the project and monitoring the megaproject impact at the local level can help to improve project performance. Therefore, the identification of relevant stakeholders should be done during the early stages of the project in order to give 
proper meaning to a development intervention. Stakeholder involvement in construction cycle is particularly important when interest groups are expected to play an active role in the implementation process and in operation and maintenance [26].

Furthermore, the involvement of stakeholders at the beginning of any project is essential to kick-start project activities. This importance is also held by Caldwel\& Usadolo [27]. In this regard, client and stakeholder presence at this stage are critical during project brief meetings [2]. In Tammer's [2] opinion, the projects briefing tries to enhance project ownership and accessibility by all concerned parties. The study by Inuwa, Saiva, and Alkizim, [28] sought to investigate the Nigerian Indigenous Contractors (NICs) in terms of their involvement, project performance, project planning challenges they faced and application of project planning techniques in building project procurement systems. The result revealed that NICs are normally involved in both traditional and non-traditional procurement systems although their frequency or level of involvement is lower particularly in the non-traditional procurement systems.

Globally, stakeholder engagement is key for project success, their role and level of engagement however differs with context. In China for example, a study by Li, Zhang, $\mathrm{Ng}$, \& Skitmore, [18] indicate that the government is the most influential entity and the extent to which its intervention is needed in balancing the interests of other stakeholders presents a major challenge. The high potential influence of end-users is also identified, suggesting the need for a more transparent and inclusive participatory decision/evaluation process. Studies by Etemire, \& Muzan [29] indicate the importance of multi-stakeholder involvement for project success. Their research is a contribution to the discourse on emerging trends in eco-restoration governance strategies by providing a critical analysis of the UNEP-led multistakeholder participatory approach to eco-restoration governance. It critically appraises the potency of UNEP's stakeholder-driven governance model as a requirement for a successful eco-restoration exercise, especially against the backdrop of, and as a better alternative to, the traditional state-driven approach.

A study by Kamanga, \& Steyn [30] in Malawi found that delay in relocating utilities and delay in paying compensation to land owners affect road construction projects. The authors assert that, "Utility organizations should be involved at the planning stage so that there is coordination and cooperation in locating and relocating these services before construction works start." In a study to determine conceptually the roaduser-costs to support decision-making process and identify both need and type of construction methods for any particular project, it is recommended that: first, utility corridors to be established and systematic location of any facilities to be done; second, many utility lines should not be relocated and that this could be facilitated by collection and mapping of the underground utility data which had earlier been undiscovered or unknown by use of subsurface utility engineering techniques in the early initiation phase (design phase); and third, utility agencies (organizations) should be able to produce more accurate and vivid as-built drawings so that information on utility location is provided for proper guidance [31].

In Kenya, many projects and especially road infrastructural projects happen in the urban areas. This is consistent with urban trends. Nyandika and Ngugi [15] in their study of the influence of stakeholders' participation recommended that KeNHA need to ensure stakeholders' involvement in order to improve its performance in road projects at Kenya National Highways Authority. Additionally, Abdalla and Otieno [17] conducted a study on the determinants of implementation of County Government projects, a case of infrastructural projects in Kilifi County in Kenya. The study revealed that community participation in project implementation of the infrastructural projects contributes to building trust and reduction of resistance to implementation of the projects by the local community members hence, improved relationships among stakeholders. Menoka, David, Damian and Edward [32] indicated that some stakeholders, particularly client and main contractor, are regarded important over the others. However, those considered less important and left out in the decision-making processes may result in a failure to address sustainability issues. Thus, it is imperative for a systematic approach to involve stakeholders with high salience in relation to sustainability. Barasa and Jelagat [16] in their study of community participation in project initiation, management and implementation, a focus on the building the foundation for sustainable development argued that, participatory development has the propensity of achieving project sustainability and increased utilization rate of the project by members of the community and sustained ownership, and further stated that, community members are important partners in national development. This clearly indicates that for achievement of national development there is need to embrace partnership and active participation of stakeholders basically at community level.

Further, Madeeha and Naqvi [33] carried a study on the impact of internal stakeholder engagement on Project Portfolio Management (PPM). The study revealed that "the ramification of stakeholders was phase-peculiar and that role clarity affected the nature of the relationship between the internal stakeholder's engagement and project portfolio management success as a moderator." This study builds on the foundation laid by this literature.

\section{Methodology}

This study used a pragmatism paradigm, to guide a mixed research approach. This allowed the research to balance the weaknesses and strengths of two approaches. Mixed research allows the researcher to describe research phenomena in both social and natural settings through research processes [34]. The unit of analysis in this study was KURA Project Implementation teams' members, KURA project planners and Directors, Road contractor's project management teams, Consultants construction supervision teams, Representatives 
of PAPs, and Complimentary service providers, making up a target population of 1593 participants. The sample size of the study was 309 participants. This was arrived at by utilizing [35] sample size determination research formula. This study obtained data from all 9 counties where KURA road projects were located through the use of a questionnaire survey and interview guide. The two tools were used for triangulation. The study then employed both descriptive and inferential statistics for the data analysis. Pearson correlation coefficient and regression analysis were conducted to identify the relationship between the independent variable (stakeholder participation in project initiation) and the dependent variable (completion of urban road transport infrastructure projects), while the amount of variance in completion of urban road transport infrastructure projects accounted for by stakeholder participation in project initiation.

\section{Results}

Data was sought and analyzed to examine the influence of stakeholder participation in project initiation on completion of urban road transport infrastructure projects in Kenya. This section presents the results of the analysis.

\subsection{Overall Descriptive Analysis of Completion of Urban Roads Transport Infrastructure Projects}

Completion of urban roads transport infrastructure projects was considered in terms of project completion within time, project completion within cost, project completion within quality and stakeholder satisfaction. The composite mean and standard deviation of these factors are shown in Table 1.

Table 1. Means and Standard Deviations of Completion of Urban Roads Transport Infrastructure Projects.

\begin{tabular}{lll}
\hline Variable Dimension/Indicator & Sub-Composite Mean (M) & Sub-composite Std. Dev. \\
\hline Project Completion within Time & 3.72 & 0.812 \\
Project Completion within Cost & 4.04 & 0.974 \\
Project Completion within Specified Quality & 4.23 & 0.837 \\
Stakeholder Satisfaction & 4.40 & 0.758 \\
Composite Mean and standard deviation & 4.10 & 0.845 \\
\hline
\end{tabular}

Results in Table 1 indicates that the overall mean of completion of urban roads transport infrastructure projects was 4.10. The most dominant indicator was stakeholder satisfaction $(\mathrm{m}=4.40)$. This is to mean that the final product met the stakeholders' needs and would serve the intended purpose as had earlier been planned. The opinions on this dimension were converging because the sub composite standard deviation was 0.758 below the composite standard deviation of 0.845 .

The second best dimension was project being completed within specified quality $(\mathrm{M}=4.23)$. Most of the opinions on this dimension were diverging since the sub composite standard deviation was 0.837 above the composite standard deviation of 0.845 .

On the dimension, project completion within cost $(\mathrm{M}=4.04)$ was not achieved because there was fluctuation of cost in fuel, materials used and the labour employed. This third dimension therefore does adversely influence road performance. Opinions on this dimension converged given the sub composite standard deviation was 0.974 below the composite standard deviation of 0.845 .

Finally, project completion within time $(\mathrm{M}=3.72)$ was not met. This is because land acquisition process for expansion of the road could have taken more time hence affecting the timelines or there was no clear dialogue and understanding between land sellers (community members) and the buyers (government) hence need to improve on this aspect. There was consistency of opinions on this dimension because the sub composite standard deviation was 0.812 below the composite standard deviation of 0.845 .

In addition, responses from interviews of the key informants seems to support the quantitative findings. When asked about the phase of the project at which Land commission officials are requested to commence the process of land acquisition for construction of urban roads projects, the land officials had some varied answers. Some said at the initiation stage when the project plans are being conceptualized, during mapping, some said after completion of designs, while most of them indicated the construction stage. One of the Land commission official said;

"We were requested to commence the process of land acquisition for construction of roads projects after completion of surveying, mapping and after acquisition plans were drawn, and mostly after all persons to be affected are identified."

Another one said;

"We usually carry out this exercise at the construction stage, when we are sure of funding from the road authorizes, since funds are need for the payment of compensation.... do you believed that they also even come running to us to start the compensation process when the contractors are already on site, ignoring that land acquisition process needs its own time to be effectively addressed".

The commission officials further noted that there is need for proper resettlement of the land owner to avoid squatters; the land owners should usually be notified in time to avoid conflicts and hindrances to enable smooth project completion.

In conducting further interviews stakeholders, KPLC officials were requested to indicate their opinion on how the process of relocation of service lines affects roads projects construction. Majority of the officials indicated that it was just before commencement of the construction, when in a meeting with the key stakeholders that the agency is often 
instructed to relocate facilities without being given adequate time for preparation to undertake the activities. One of the KPLC official said,

"I was requested to commence the process of removal and relocation of service lines to pave way for construction of outer ring road, after mobilization of the contractor".

Another official said,

"We are mostly asked to commence the process of removal and relocation of service lines for construction of roads immediately after the design is completed and after it has received approvals from all the concerned authorities. However, the request is usually not followed prompt payment of our relocation cost which intends leads further delays in project and also trigger some external socioeconomic cost the public".

When project beneficiaries, through representatives of resident associations were asked to indicate their opinions on level of their satisfaction with the completed roads projects. Most of the respondents indicated that the benefit of the completed road projects was enhanced value of their land parcels, decrease in insecurity, easy transportation, and creation of employment. One of the affected person said,

"Good roads always come with a boost in the economic growth and that means I stand to benefit in the process as a business owner".
Also, most of the Matatu SACCO representative indicated that fares have dropped as a result of the completion of the roads. One of the SACCO representative said,

"Yes, the fares were affected because they dropped by almost 50\% whereby there is not much profit made by the car owners instead appears to be helping the residents with transportation mode".

Another SACCO representative said,

"The vehicle operating costs reduced drastically because the roads are in good condition and the vehicles hardly get damaged like before, so, the vehicles do not spend much money going to garages for repair as before".

In terms of time saving, a SACCO representative said,

"The time taken to take people from one destination to another has reduced from one hour to almost 15 min during normal hours and 30 min during pick hours".

\subsection{Descriptive Analysis of Stakeholder Participation in Project Initiation}

Participation in project initiation was considered in terms of stakeholder identification, setting goals/objectives, needs assessment and feasibility study. From the descriptive analysis, the overall composite means and standard deviations of these factors are shown in Table 2.

Table 2. Means and Standard Deviations of Participation in Project Initiation.

\begin{tabular}{lll}
\hline Variable Dimension/Indicator & Sub-composite Mean (M) & Sub-composite mean Std. Dev. \\
\hline Stakeholder identification & 3.82 & 0.822 \\
Setting Goals/objectives & 2.91 & 0.985 \\
Needs Assessment & 3.40 & 1.017 \\
Feasibility study & 3.85 & 0.859 \\
Composite mean and standard deviation & 3.495 & 0.921 \\
\hline
\end{tabular}

Results in Table 2 indicate that the overall mean or composite mean of participation in project initiation was 3.495. The most dominant indicator was feasibility study $(\mathrm{M}=3.85)$, whereby the study findings showed that the stakeholders were involved in the consultative meetings for environmental and social impact assessment studies. The opinions on this indicator converged given the sub composite standard deviation was 0.859 below the composite standard deviation of 0.921 .

The indicator, stakeholder identification $(\mathrm{M}=3.82)$, followed second in terms of rating. The study revealed that stakeholder's identification was carried out during project initiation phase. The stakeholders were engaged through letters, email, and advertisement in local newspapers. It also emerged that the county government was identified as a vital stakeholder to the project. In addition, stakeholders' interest, power and influence was analyzed to assist in establishing how to manage them. Further, community was considered a vital stakeholder to the success of the project. The opinions on this indicator converged since the sub composite standard deviation was 0.822 below the composite standard deviation of 0.921 , implying opinion of respondents converged.
The indicator, needs assessment $(\mathrm{M}=3.40)$ appeared to have had an average significance influence on the performance of the road. It was evident from the analysis that a needs assessment survey was carried out through interviews. The opinions on this indicator diverged given the sub composite standard deviation was 1.017 and the composite standard deviation of 0.921 .

The indicator, setting goals/objectives $(M=2.91)$, did not influence the performance of the road. The study revealed that the community was not consulted and did not contribute in setting of the project goals and objectives during project initiation phase. Only key stakeholders were consulted in setting of the project objectives during project initiation phase. In addition, views of the community along the project roads into were put into consideration in setting of goals and objectives. Moreover, only the key project teams were involved in preparing a realistic timeframe for completing the project goals. The opinions on this indicator were inconsistent because the sub composite standard deviation was 0.985 above the composite standard deviation of 0.921 .

Information from specific interviews conducted with the professional stakeholders and complimentary service 
providers such as KPLC, NLC, and water service boards, also confirmed some of the major findings of the quantitative data. The respondents further indicated that stakeholders have inadequately participated in optimal decision making, designs and requirements that suit their needs at the initial stages; especially during the feasibility studies of the project and planned project activities.

One of the KPLC stakeholder, said;

"...most of us were not consulted when some of these important projects were being initiated and for which we could not make meaningful suggestion that could have added value to the purpose of the projects. Our institution was only requested information on our major service lines".

Another stakeholder from the Land Commission said;

We are not usually adequately involved at that stage. The project implementers will only call on us when there are disagreements and conflicts from the land owners as a result of the project, and this situation often tend bring abnormal increases in land values due to activities of land speculators. This at times lead to undue projects cost and major delays in completion of road projects".

A representative from the Matatu SACCO also said, "..., we were never involved and we don't know how the decision were arrived at on the location of bus stops and points of foot bridges were located because they are not serving us properly".

When asked about the challenges they faced in the process of land acquisition/relocation of service lines to facilitate road construction, most of the PAPs said that they had to close business and hence experienced loses, loss of customers far from the road and there is a lot of dust and it is affecting their health. This is an indication that land acquisition for projects posed a lot of challenges. For instance, one of the PAPs said,

"...I was not notified about the commencement of the project on time. I just woke up on the shocking news of the destruction of my wall that covered my compound". Another affected person said "I was not informed and the contractor was very rude he did not allow me to move my things away from destruction. They destroyed my belongings without even caring".

When asked when they were notified to move out of the land to give way to the construction of the road, most of the affects persons said three months prior to the commencement and others were given one-month notice to vacate the land. Another affected person said,

"...The project team came and told me my bar was built on a road reserve and I had to relocate (demolish) the building".

Another one said:

"I was given a one-month notice which was too short that did not allow me to be prepared and move out and also the compensation was not done in that one month".

When asked about the challenges they face in relocation of the service line for construction of urban roads, most of the officials of water companies said that leakage of sewer, customer's complaints, damages to pipes, unplanned cost of relocation and conflicts with service providers on utility tunnel. One of the water company official said,

"... One of the challenge I have ever faced in relocation of service line is that leakage in sewer lines may create a bad image of the company which may affect delivery of services to residents".

Another water official said,

"Among the challenges I have while relocating the services lines are complaints from the residents due to water supply being cut short and sewer lines leaking to the environment, lack of readily available service line conduits or routes to install our service lines, damage to the sewer line which caused havoc to the environment and this may also affect the residents around and unplanned costs of relocating the service lines also a challenge we face during such situations".

Another water company official said.

"There are cases where we are not allowed to relocate our services lines to a road way-leave which also complicated relocation due to the legalities of such activities and assigning the right resource and organization to carry out the process and this led to late completion of the project".

In effect, the findings from the quantitative and qualitative data indicate that there participation in project initiation influences positively the completion of urban road transport infrastructure projects. This therefore, justified the rationale for conducting this study using mixed research method. It further shows that project managers should as much as possible try to consult and engage the necessary key project stakeholders in the initial stages of road infrastructure projects in order to enhance their effective and efficient completion.

\subsection{Correlation Analysis of Stakeholder Participation in Project Initiation}

Analysis was carried out to establish the direction and magnitude of the relationship between the independent and dependent variables under investigation. This was in line with the objective of this study, which was to establish how participation in project initiation influences the completion of urban road transport infrastructure projects in Kenya. Participation in project initiation was measured by stakeholder identification, setting goals/objectives, needs assessment and feasibility study while completion of urban roads transport infrastructure projects was measured by project completion within time, project completion within cost, project completion within quality and stakeholder satisfaction. Data was collected from the respondents on participation in project initiation indicators and then the composite index on each of the participation in project initiation variable indicators (stakeholder identification, setting goals/objectives, needs assessment and feasibility study) was computed and used in the analysis. The results are presented in Table 3. 
Table 3. Correlation between Participation in Project Initiation and Completion of Urban Road Transport Infrastructure Projects.

\begin{tabular}{lllllll}
\hline & & $\begin{array}{l}\text { Stakeholder } \\
\text { identification }\end{array}$ & $\begin{array}{l}\text { Setting } \\
\text { Goals/objectives }\end{array}$ & $\begin{array}{l}\text { Needs } \\
\text { Assessment }\end{array}$ & $\begin{array}{l}\text { Feasibility } \\
\text { study }\end{array}$ & $\begin{array}{l}\text { Participation in } \\
\text { Project Conception }\end{array}$ \\
\hline Completion of urban road & Pearson Correlation & 0.806 & 0.711 & 0.622 & 0.772 & 0.859 \\
transport infrastructure projects & Sig. (2-tailed) & 0.023 & 0.027 & 0.028 & 0.042 & 0.015 \\
& n & 214 & 214 & 214 & 214 & 214 \\
\hline
\end{tabular}

Table 3 indicate strong correlation between the completion of urban road transport infrastructure projects and stakeholder identification whose $\mathrm{r}=0.806$ which meant that stakeholder identification was significant since and $\mathrm{p}=0.023<0.05$; setting goals and objectives had a $\mathrm{r}=0.711$ which was significant as $\mathrm{p}=.027<0.05$ hence was also significant; feasibility studies was also found to be significant since it had a $\mathrm{r}=0.622$ and $\mathrm{p}=0.028<0.05$; and needs assessment was significant since $\mathrm{p}=0.042<0.05$ and $\mathrm{r}=0.772$. There was a strong correlation between the completion of urban road transport infrastructure projects and participation in project initiation $(\mathrm{r}=0.859)$ and the relationship was significant $(\mathrm{p}=0.015<0.05)$.

\subsection{Regression Analysis of Influence of Participation in Project Initiation on Completion of Urban Road Transport Infrastructure Projects}

Further Linear regression analysis was conducted to establish the influence of participation in project initiation on completion of urban road transport infrastructure projects in Kenya.

Data was analyzed and the regression results for the influence of participation in project initiation on completion of urban road transport infrastructure projects in Kenya are presented in Table 4.

Table 4. Participation in Project Initiation and Completion of Urban Road Transport Infrastructure Projects.

\begin{tabular}{|c|c|c|c|c|c|c|}
\hline \multicolumn{7}{|c|}{ Model Summary } \\
\hline Model & $\mathbf{R}$ & R Square & \multicolumn{2}{|c|}{ Adjusted R Square } & \multicolumn{2}{|c|}{ Std. Error of the Estimate } \\
\hline 1 & 0.859 & 0.737 & \multicolumn{2}{|c|}{0.736} & \multicolumn{2}{|c|}{1.173} \\
\hline \multicolumn{7}{|c|}{ ANOVA } \\
\hline Model & & Sum of Squares & df & Mean Square & $\mathbf{F}$ & Sig. \\
\hline \multirow{2}{*}{1} & Regression & 818.029 & 1 & 818.029 & 594.869 & .000 \\
\hline & Residual & 291.53 & 212 & 1.375 & & \\
\hline Total & & 1109.559 & 213 & & & \\
\hline
\end{tabular}

\begin{tabular}{|c|c|c|c|c|c|c|}
\hline \multicolumn{7}{|c|}{ Regression Coefficients } \\
\hline \multirow{2}{*}{ Model } & & \multicolumn{2}{|c|}{ Unstandardized Coefficients } & \multirow{2}{*}{$\begin{array}{l}\text { Standardized Coefficients } \\
\text { Beta }\end{array}$} & \multirow{2}{*}{$\mathbf{t}$} & \multirow{2}{*}{ Sig. } \\
\hline & & $\mathrm{B}$ & Std. Error & & & \\
\hline 1 & (Constant) & 0.897 & 0.198 & & 4.530 & .000 \\
\hline & Participation in Project Initiation & 0.889 & 0.143 & 0.859 & 6.217 & .000 \\
\hline
\end{tabular}

Predictors: (constant), Stakeholder identification, setting goals/objectives, Needs assessment, Feasibility study, Participation in Project Initiation. Dependent Variable: Completion of urban road transport infrastructure projects.

Table 4 shows that $r=0.859$. This indicates that participation in project initiation has a strong relationship with completion of urban road transport infrastructure projects in Kenya. $\mathrm{R}^{2}=0.737$ indicating that participation in project initiation explains $73.7 \%$ of the variations in the completion of urban road transport infrastructure projects in Kenya. The overall $\mathrm{F}$ statistics, $(\mathrm{F}=594.869, \mathrm{p}<0.000<0.05)$, indicated that there was a very statistical significant relationship between participation in project initiation and completion of urban road transport infrastructure projects in Kenya. The null hypothesis was therefore rejected and it was concluded that participation in project initiation significantly influences completion of urban road transport infrastructure projects in Kenya.

\section{Discussion of Findings}

The findings revealed that participation in project initiation significantly influences the completion of urban road transport infrastructure projects in Kenya. This is consistent with Aapaoja, Haapasalo and Söderström [5] on the critical role of stakeholders in the initial stages of the project. The current study however, differs with the study on the influence of project initiation on the completion of Government road infrastructure projects in Kenya, a case of Meru County [35]. This means that the significance of stakeholder involvement is contextual and their role will vary from project to project. The qualitative views gathered from the respondents in the current study shows that there was participation of stakeholders in the initiation stage of the project which built the trust of the stakeholders. The findings resonate with Abdalla \& Otieno [17] whose study found that stakeholder participation contributes to building trust and reduction of resistance to implementation of the projects by the local community members hence, improved relationships among stakeholders.

The quantitative results further showed that the community and other stakeholders were involved in the 
consultative meetings for environmental and social impact assessment studies. Stakeholders were also involved in determination of the capacity of the road including economic and financial viability of the project. They were however not involved in establishing the scope of the project based on available funds since this activity was reserved for the key stakeholders. This concurs with Amadi [10] who notes that the whole community should be involved by allowing them to participate in the initiation and design phase of the project, to provide views on what they consider important including the operationalization or execution of the project.

Another finding from the qualitative analysis was that the agency dealing with land acquisition for road expansion were not contacted early enough and neither were the land owners and squatters notified of the upcoming construction of the roads in good time. This supports the findings of Inuwa, Saiva, Alkizim [28] and Kamanga, \& Steyn [30], who observed that community affected by the construction as their properties are along road reserve needs to be proclaimed and given notice in time during early stage of the planning; in addition, the extent to which they participate must be increased or improved. The current study affirms what Goodrum, Wan, \& Fenouil [31] found and recommended that systematic location of any facilities need to be carried out by ensuring not many utility lines are relocated and that mapping and collection of underground utility data to provide needed information.

\section{Conclusion}

The study makes the following conclusions:

That for the participation in project initiation had the strong positive correlation with project completion. Although all the stages are important of the project cycle are important this study places emphasis the initiation stages for because it lays a solid project foundation. Stakeholder identification at initiation stage promotes the engagement of the stakeholders which eventually influence the overall completion of urban road transport infrastructure projects.

That, there was inadequate consultation of utility service providers, the commission responsible for land acquisition and Project Affected Persons (PAPs) at the initiation stage of the construction project and this adversely affected completion of urban road transport infrastructure projects. That stakeholder identification, needs assessment, goals and objective setting and feasibility studies all influence completion of urban road transport infrastructure projects in Kenya.

\section{Recommendations}

The following recommendations are drawn from the study. First, from the qualitative responses it emerged that there is need for a framework for stakeholder involvement that should constitute (i) selection of stakeholders (ii) Orientation and (ii) training. Second, that competent and experienced project managers should be hired to ensure that the right project leadership team is put in place to lead an effective implementation of urban road transport infrastructure. Fourth, that during project initiation stakeholders and all the team members of the project should be involved to enhance the success of a project. Fifth, that effective project design and initiation activities should be applied to all projects while adopting and continuously enforcing project management best practices.

\section{References}

[1] Pheng L. S. (2018) Project Life Cycles, Stakeholders and Organizations. In: Project Management for the Built Environment. Management in the Built Environment. Springer, Singapore.

[2] Tammer, M. (2009). Early stakeholder involvement in projects; Maturity Model for Construction Firms. Published in Institute for Business Engineering, Utrecht University of Applied Science, Faculty of Natural Sciences \& Technology.

[3] Ning Y. and Mao Y., (2011) "The risk monitoring of coal construction project based on system dynamics model," Proceedings of International Conference on Information Systems for Crisis Response and Management (ISCRAM), Harbin, Heilongjiang, 2011, pp. 330-334.

[4] Lennon, B., Dunphy, N. P. \& Sanvicente, E. Community acceptability and the energy transition: a citizens' perspective. $\begin{array}{lllll}\text { Energ Sustain Soc 9, } & 35 & \text { (2019). }\end{array}$ https://doi.org/10.1186/s13705-019-0218-z.

[5] Aapaoja A, Haapasalo H, Söderström P. (2013) Early Stakeholder Involvement in the Project Definition Phase: Case Renovation, ISRN Industrial Engineering, Volume 2013, Article ID 953915, $14 \quad 14$ pages http://dx.doi.org/10.1155/2013/953915.

[6] Aziz R. F, Hafez S, H. (2013) Applying lean thinking in construction and performance improvement, Alexandria Engineering Journal, Volume 52, Issue 4, December 2013, Pages 679-695.

[7] Chikati, J. (2009). Participatory Project Identification and Planning, A Regional Partnership for Resource Development publication. Nairobi: Signal Press Ltd.

[8] PMI \& PMBOK. (2013). A Guide to Project Management Body of Knowledge, 5th Ed. Newtown Square: Project Management Institute.

[9] Petersen, K. J., Handfield, R. B., \& Ragatz, G. L. (2003). A model of supplier integration into new product development. Journal of Product Innovation Management, 20 (4), 284-299. https://doi.org/10.1111/1540-5885.00028.

[10] Amadi, J. O. (2017). The Role of Planning on Performance of Community Projects in Kenya. Developing Country Studies, 7 (1), 1-7.

[11] Menoka, B (2014) Stakeholder Engagement and Sustainability-Related Project Performance in Construction. Doctoral thesis, Liverpool John Moores University.

[12] Freeman, R. E. (1984). Strategic Management: A Stakeholder Approach. Boston: Pitman Press, Boston, Ma p 46. 
[13] Harrison, Jeffrey S., Douglas A. Bosse, and Robert A. Phillips.(2012) "Managing for Stakeholders, Stakeholder Utility Functions, andCompetitive Advantage." In New Directions in Business Ethics, edited by Andrew Crane and Dirk Matten, 149-74. Vol. IV. Los Angeles: SAGE, 2012.

[14] Freeman, R. E., Harrison, J., Wicks, A., Parmar, B. and de Colle, S. (2010). Stakeholder theory: The state of the art, Cambridge: Cambridge University Press.

[15] Nyandika, O. F \& Ngugi, K. (2014). Influence of Stakeholders' Participation on Performance of Road Projects at Kenya National Highways Authority. European Journal of Business Management, 1 (11), 384-404.

[16] Barasa, F. \& Jelagat, T. (2013). Community Participation in Project design, Management and Implementation: Building the Foundation for Sustainable Development. International Journal of Current Research, 5 (2), 398-401.

[17] Abdalla, A. \& Otieno, M. (2017). Determinants of Implementation of County Government Projects: A Case of Infrastructural Projects Inkilifi County, Kenya. International Journal of Latest Research in Engineering and Technology, 3 (9), 108-118.

[18] Li, H. Y., Zhang, X. L., Ng, S. T \& Skitmore, M. (2017) Quantifying stakeholder influence in decision/evaluations relating to sustainable construction in China - A Delphi approach. J Cleaner Prod. doi: 10.1016/j.jclepro.2017.04.151.

[19] Lindborg, H. J. (2013). "Stake Your Ground: Unearthing the origins of stakeholder management". Quality Progress, 2 (1), $1-3$.

[20] Oliveira, G. F. \& Rabechini Jr, R. (2019). Stakeholder management influence on trust in a project: A quantitative study. International Journal of Project Management, 37 (1), 131-144.

[21] Patrick. X. W. Zou \& Guomin Zhang (2009) Managing Risks in Construction Projects: Life Cycle and Stakeholder Perspectives, International Journal of Construction Management, 9: 1, 61-77, DOI: 10.1080/15623599.2009.10773122.

[22] Abowitz, D. \& Toole, T. (2010). Mixed method research: fundamental issues of design, validity, and reliability in construction research. Journal of Construction Engineering and Management, 136 (1), 108-116.

[23] Hassan A I (2012). Influence of stakeholder's role on performance of constituency development fund projects a case of Isiolo North Constituency, Kenya. Unpublished Masters in project design and management, University of Nairobi.

[24] Mulwa, F. W. (2006). Participatory monitoring and evaluation of community projects. Community Based Project
Monitoring, Qualitative Impact Assessment and People Friendly Evaluation Methods. Eldoret: Zapf Chancery and P. Olivex Publishers.

[25] Maddaloni F, D. and Davis, K. (2017) The influence of local community stakeholders in megaprojects: Rethinking their inclusiveness to improve project performance. Volume 35, Issue 8, November 2017, Pages 1537-1556 https://doi.org/10.1016/j.ijproman.2017.08.011.

[26] Paton, S. \& Andrew, B. (2019). The role of the Project Management Office (PMO) in product lifecycle management: A case study in the defence industry. International Journal of Production Economics, 208 (2), 43-52.

[27] Caldwel, M., \& Usadolo, S. (2016). A Stakeholder Approach to Community Participation in a Rural Development Project. An article distributed by the Creative Commons Attribution.

[28] Inuwa, I. I., Saiva, D., Alkizim, A. (2014). Investigating Nigerian indigenous planning in Construction Procurement: An Explanatory Approach. International Journal of Civil \& Environmental Engineering, 14 (4), 16-25.

[29] Etemire, U. \& Muzan, M. A. (2017) Governance and regulatory strategies beyond the state: stakeholder participation and the ecological restoration of Ogoniland, Griffith Law Review, 26: 2, 275-298, DOI: 10.1080/10383441.2017.1366253.

[30] Kamanga, M. J, \& Steyn, W. (2013). Causes of delays in road construction projects. The Journal of South African Institution of Civil Engineering. 55 (3), 79-85.

[31] Goodrum, P M, Wan, Y \& Fenouil, P. C. (2009). A decision making system for accelerating roadway construction. Engineering, Construction and Architectural Management, 16 (2), 116-134.

[32] Menoka, B, David, B., Damian, F., \& Edward, O. (2013). Stakeholder Engagement: Achieving Sustainability in the Construction Sector. Sustainability 2013, 6, 695710; doi: $10.3390 /$ su5020695.

[33] Madeeha, S. \& Naqvi, I. H. (2014). Impact of Internal Stakeholder's Engagement on Project portfolio Management Success, IT Industry in Lahore, Pakistan. Sci. Int. (Lahore), 26 (4), $1777-1782$

[34] Sarantakos, S. (2013). Social Research. (4th Ed.). Melbourne: MacMillan Educational.

[35] Yamane, T. (1967). Statistics: An introductory analysis. New York: Harper \& Row.

[36] Kithinji, S. K. (2017). Influence of Project Conception on the Completion of Government Road Infrastructure Projects In Kenya, A Case of Meru County. Doctoral Dissertation, Nairobi University. 